\title{
European perspective on the development of planted forests, including projections to 2065
}

\author{
Gert-Jan Nabuurs $^{1 *}$, Mart-Jan Schelhaas ${ }^{1}$, Christophe Orazio² ${ }^{2}$ Geerten Hengeveld ${ }^{1,3}$, Margarida Tome ${ }^{4}$, \\ Edward P Farrell ${ }^{5}$ \\ From Third International Congress on Planted Forests \\ Bordeaux, France; Dublin, Ireland; and Porto and Estoril, Portugal. 16-21 May 2013
}

\begin{abstract}
Background: The 27 countries in the European Union have a combined total of 177 million ha of forested and other wooded land. These are mainly characterised as semi-natural, multi-functional forests. Only about 13 million ha are characterised as plantations', although an additional 47 million ha are regarded as planted forests (Forest Europe 2011). European forests are highly diverse due to centuries of management in countries with different cultural objectives. Often the current management is nature oriented and so forests may not be used primarily for wood production. Wood provides only a small part of the income for many of the 16 million private owners according to the Confédération Européenne des Propriétaires Forestiers (CEPF 2013). These circumstances, plus sluggish demand for wood brought about by the current economic crisis, have generated challenges for the forestry sector. Demand for wood is expected to increase with expansion of the green economy and an increased emphasis on the use of bioenergy.
\end{abstract}

Methods: Three forest management scenarios (analysed with the EFISCEN model) were used to project supply in response to demand for wood from EU forests over the next 50 years.

Results: Shortening of broadleaved forest rotation length and planting $50 \%$ of the felled area with fast-growing coniferous species could increase coniferous wood supply from 473 to 561 million $\mathrm{m}^{3} \mathrm{y}^{-1}$. Demand could reach more than 1200 million $\mathrm{m}^{3} \mathrm{y}^{-1}$ by 2065 .

Conclusions: Conversion of 50\% of broadleaved forest in EU27 countries to coniferous forest is not likely to satisfy the increased demand for wood expected by 2065.

\section{Introduction}

The 27 countries currently in the European Union (EU27) have 177 million ha of forest and other wooded land (Forest Europe, 2011). Only about 13 million ha are characterised as plantations, although an additional 47 million ha are regarded as planted forests, which represents $26 \%$ of the total global planted forest area (ForestEurope 2011). Most European forests are actively managed and there is great diversity in terms of management objectives, forest types and species (Figure 1). The distinction between natural and planted forest is

\footnotetext{
* Correspondence: gert-jan.nabuurs@wur.nl

${ }^{1}$ Alterra, Wageningen University and Research, P.O. Box 47, 6700 AA

Wageningen, The Netherlands

Full list of author information is available at the end of the article
}

less clear than for other world regions as much of the original forest cover was removed in early Medieval times, and reafforestation has taken place steadily since the 1700s. Recent increases in forest area in EU27 (on average 506,000 ha per year from 2005 to 2010; Forest Europe 2011) result both from the establishment of planted forests using mainly native species and from natural colonisation of former agricultural land.

This paper firstly outlines the current trends and issues regarding resources, climate change and socioeconomic factors in European forests. Then the predicted effects of three forest management scenarios on wood productivity over the next 50 years are compared and an assessment made of the extent to which new

\section{SpringerOpen ${ }^{\circ}$}

(c) 2014 Nabuurs et al.; licensee Springer. This is an Open Access article distributed under the terms of the Creative Commons Attribution License (http://creativecommons.org/licenses/by/2.0), which permits unrestricted use, distribution, and reproduction in any medium, provided the original work is properly cited. 


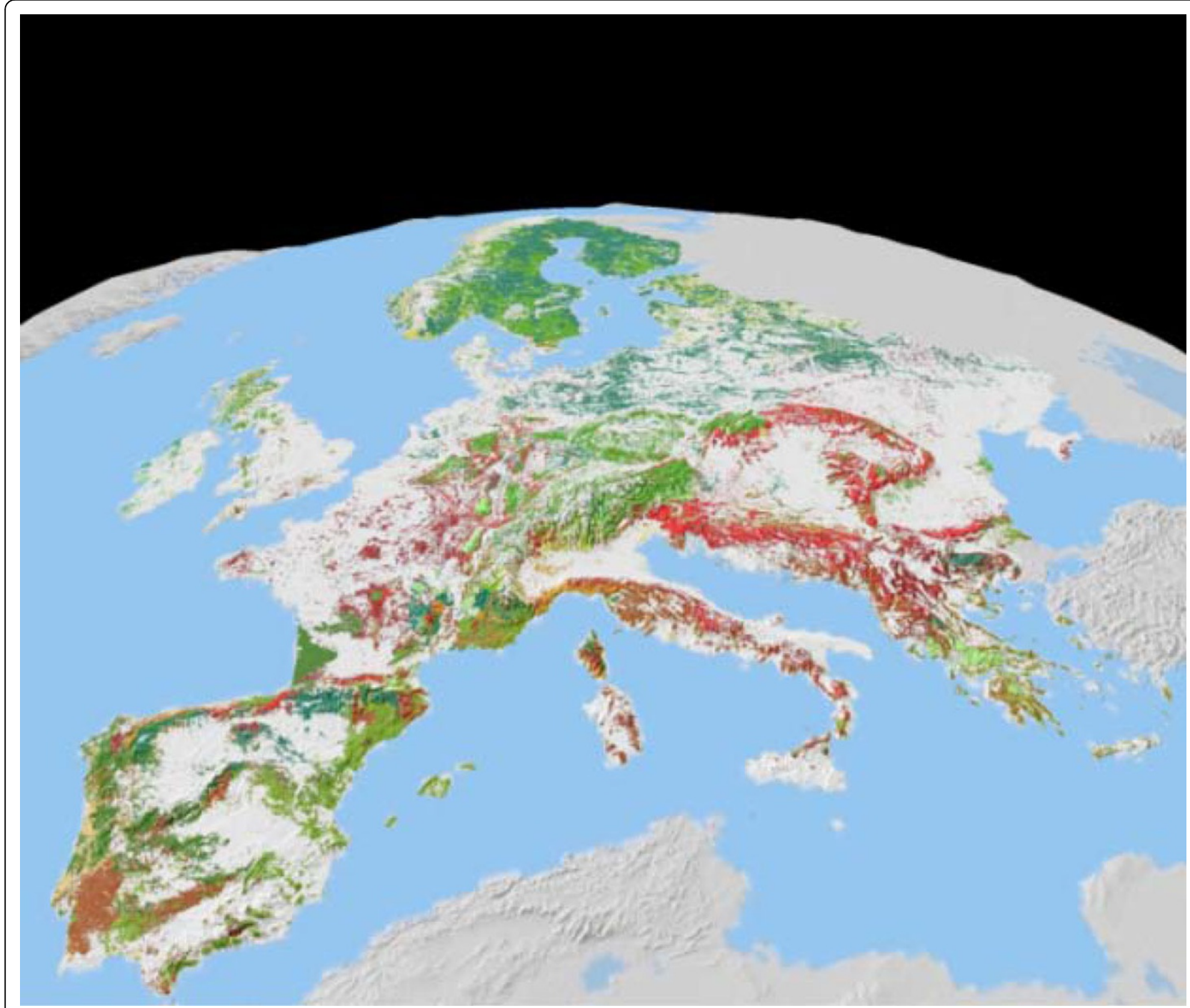

Figure 1 Map showing heterogeneity of tree species and their distribution in Europe. Data sources: Brus et al. (2011); Hengeveld et al. (2012); Nabuurs et al. (2009).

plantations could cover any shortfall in wood supply in the future.

\section{Current trends and issues}

\section{Resources}

Growing stock in EU27 forests currently amounts to a volume of 24.1 billion $\mathrm{m}^{3}$ (ForestEurope 2011). Although the area covered is probably greater than since early Medieval times, this current volume of standing timber is mainly due to increasing increments over time, and to a harvesting level which is $65 \%$ of increment because of a demand which is only at this level, and improved recycling rates (ForestEurope 2011). Thus, at any specified age, forests currently contain more wood than they did in the 1950s (Vilén et al, 2012). Furthermore, the average age of European forests has increased since the 1980s. Net annual increment in EU27 forests amounts to 620 million $\mathrm{m}^{3} \mathrm{y}^{-1}$, and felled timber to $469 \mathrm{~m}^{3} \mathrm{y}^{-1}$ (Forest Europe 2011). However, there are indications that high stocking rates are making European forests more vulnerable to natural disturbances of which storms are the most important one (Schelhaas et al, 2003, Seidl et al. 2011).

\section{Climate change}

Any change in climate could alter the suitability of specific sites for particular species and provenances, thus influencing the whole forest ecosystem. A large, potentially negative economic impact on the forest sector is possible, especially in the Mediterranean region although medium long-term growth increases in Central and Northern Europe may occur as well (Hanewinkel et al., 2012). In this event it would be necessary to adapt to 
changing conditions either by increasing the natural adaptive capacity of trees (e.g. by enhancement of genetic and species diversity) or through planned management systems, such as use of alternative species (Bolte et al., 2009). Up to now, few guidelines exist for the selection or implementation of methods for achieving these objectives (Lindner et al., 2010)

\section{Socio-economic factors}

Future management of planted forests will need to take into account: the high degree of fragmentation of private forest ownership, the effect of the current economic crisis on demand for timber, product innovation, optimisation of the value-added chain, and the increasing role of the forestry sector in the bio-economy.

The onset of the global financial crisis in 2008 and the economic consequences have resulted in a considerable decrease in demand for certain wood products. For instance, pulp and paper production in Europe declined by more than $11 \%$ during the following year (Figure 2) and signs of full recovery are not there yet. A similar situation has also occurred in the USA.

This downturn in pulp and paper production, and a concurrent increase in demand for bioenergy has led to a fundamental shift in the forestry and forest industry sectors. Some countries have responded with economic stimulus packages designed to promote the development of a "greener" economy.

Currently, the forest industry sector provides only a small proportion (approximately 1\%) of European GDP (ForestEurope 2011). In case of a forest coverage of a large proportion of land (60-70\%), then the sector contributes roughly $3 \%$ (Figure 3 ). This is low partly due to fragmented forest ownership, with the average size of a private forest holding being just 2.7 ha, but also because of high levels of industrialisation in these countries. However, numerous downstream effects demonstrate that the importance of forestry in the European economy extends

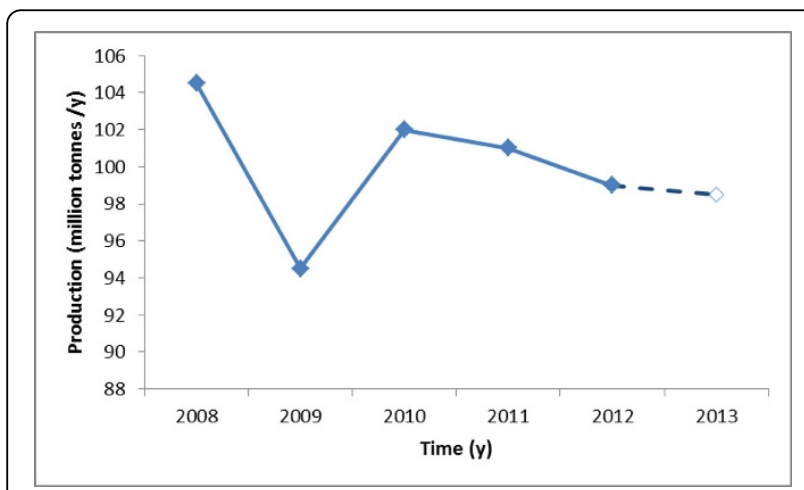

Figure 2 Industrial production of pulp and paper in Europe. The value for 2013 is an estimate (after UNECE/FAO, 2013).

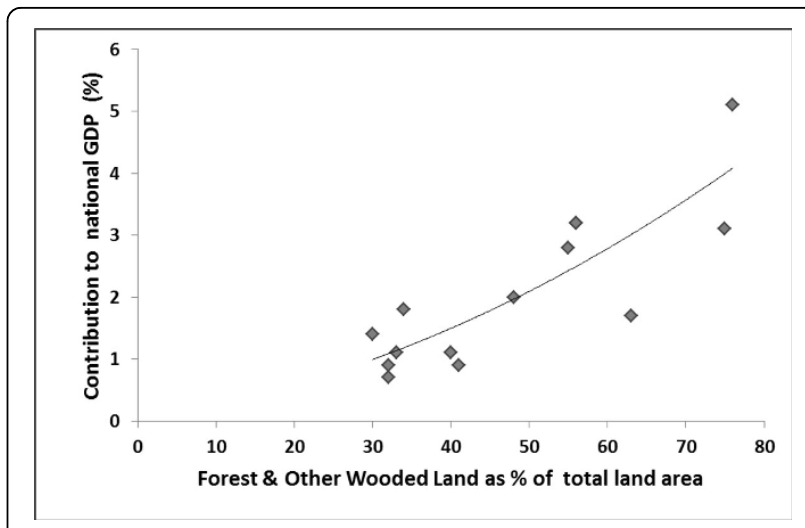

Figure 3 Relationship between area of land covered by forests and other wooded land (FOWL) and the contribution made by the forest sector to national GDP (Source: Forest Europe 2011).

beyond sectoral boundaries. Consideration of the broader forest value chain (including effects on construction, transport, packaging, bio-energy and tourism) increases contribution to GDP to $8 \%$; even when we ignore the large contribution through environmental ecosystem services such as recreation, carbon sequestration, water protection etc.

\section{Use of multifunctional forests to satisfy timber demand}

European forest management is characterised by its multi-functionality. At various levels (tree stand, landscape, nation), contrasting approaches may involve either more integration or more segregation. Examples of objectives that can be achieved at the same time as wood production are biodiversity conservation, recreation, carbon sequestration and water protection (Farrel et al., 2000). There are indications that segregation is becoming more frequent. For example, the area of protected forest in Europe increased by $12 \%$ to around 30 million ha between 2000 and 2010. Approximately $22 \%$ of this protected area is subject to zero or minimal intervention; the remainder is actively managed to increase biodiversity with minor restrictions placed on timber production (Forest Europe 2011).

There is on-going debate about which methods are suitable for satisfying the increasing demand for wood for energy while maintaining traditional forestry land use and multi-functionality. The latest European Forest Sector Outlook Study (EFSOS, 2011) projects an increase in the use of woody biomass for energy production. This implies greater competition for wood resources and a need for careful attention to minimum and maximum extraction of the annual increment. According to these projections, there will be a shortfall in the supply of woody biomass by 2030. Nabuurs et al. (2006) also predicted a shortfall in wood supply of 185 million $\mathrm{m}^{3}$ per year by 2050 due to increased demand for bioenergy and the implementation 
of set-aside policies for nature conservation. Coniferous wood is expected to be particularly scarce as a result of the trend towards management of broadleaved forests. Mantau et al. (2010) predicted a shortfall even under a high-supply scenario in which wood, once harvested, would be used with minimum wastage.

These studies suggest that there is a need for (a) increased domestic wood production in some forested regions through stimulation of rational and commercially interested forest ownership, (b) extension of the area allocated to wood production through increase in the number of planted and short-rotation coppiced forests, and/or (c) optimisation of management methods throughout the extended value chain.

\section{Effect of planting coniferous trees}

The aim here was to asses to what degree and over what time span an increased conversion of existing broadleaved forests to planted coniferous forests could cover an increased demand for wood by studying the effects of implementing Option (b) above.

\section{Methods}

Total forest resources (142 Mha) of 25 EU countries ${ }^{\text {ii }}$ were examined using the EFISCEN model. EFISCEN is an area-based matrix model that assesses the availability of wood and projects forest resource development. It is especially suitable for large-scale forest scenario projections at a country or a regional level (Sallnäs 1990; Nabuurs et al., 2006; Schelhaas et al. 2007). The same forest resource database as underlying the UNECE Forest Sector Outlook studies has been used (UNECE/FAO 2011). The model simulates the development of the forest resources in terms of integrating data on wood increment, growing stock, forested area, tree species and age class distribution in time steps of five years, usually for periods of 50-60 years. A detailed description of the model is given by Schelhaas et al. (2007).

In EFISCEN, the state of the forest is described by distribution of age and volume classes, using inventory data for the forest area available for wood supply. Transitions of area data between matrix cells during simulation reflect natural processes and are influenced by management regime and change in forested area. Growth dynamics are simulated by shifts in area between matrix cells. In each 5-year time step, the area in each matrix cell moves up one age class to simulate ageing. Part of the area in each cell also moves to a higher volume class. Growth dynamics are estimated by mathematical functions with coefficients based on inventory data or yield tables.

Management was specified at two levels in the model. Firstly, a basic forest management regime defined the period during which thinnings could take place and a minimum age for final felling. These regimes can be regarded as constraints on the total harvest level. Thinnings were simulated by shifting the specified area to a lower volume class. Final felling was simulated by shifting the specified area outside the matrix to a separate "bare-forest land" class. Shifting bare-forest land back into the matrix simulated replanting or regeneration. Secondly, the demands for wood from thinnings and from final felling were specified separately, and EFISCEN simulated the felling of the required wood volume, if it is available.

The study was confined to forest tree species and management regimes that are already specified in EFISCEN for particular countries. A typical conversion of land to fastgrowing coniferous forest (e.g. Pinus and Picea spp.) with rotation length of 40-80 years was simulated rather than a more extreme conversion to short-rotation Eucalyptus or Populus spp. forest. This conversion method was selected as the most logical and economical change. Furthermore, few countries have poplar or eucalypt species parameterised in EFISCEN thus hampering a large-scale conversion to these species in the model. Further, although poplar and willow are interesting from bioenergy and growth-rate points of view, they mostly grow in floodplains where no new areas are available, as these are in intensive use for agriculture. Assumptions for all Scenarios were that forest owners would be willing to harvest at the specified felling age.

The following three scenarios were examined:

1) Business as Usual (BAU): European Forest Sector Outlook Reference Scenario based on the The European forest sector outlook study II. 2010-2030 (UNECE/FAO 2011).

No species change. Increase in wood demand of $0.6 \% \mathrm{y}^{-1}$. Increased growth rates due to climate change.

\section{2) High demand + Change of tree species (Plantation)}

At final felling of most broadleaved species, $50 \%$ of the area is converted to a faster-growing coniferous species.

Higher increase in wood demand of $2 \% \mathrm{y}^{-1}$ during the first time step of 5 years. This equals 64 million $\mathrm{m}^{3}$ per 5 years. In order to avoid an exponential increase in demand, we increase demand in subsequent periods with the same 64 million $\mathrm{m}^{3} 5 \mathrm{y}^{-1}$.

3) High demand + Change of tree species and shortening rotation length (Plantation+)

As for (2) but the rotation length of the broadleaved species is shortened to 20 years in order to increase the rate of future conversion to conifer plantations. 


\section{Results}

Simulation of the BAU Scenario indicated that European forests could supply almost all of the increase in demand $\left(0.6 \% \mathrm{y}^{-1}\right)$ until 2065 with minimal change in management (Figure 4). Coniferous forests (just over half of the total forest area) could supply 473 million $\mathrm{m}^{3} \mathrm{y}^{-1}$ in 2065, an increase of 103 million $\mathrm{m}^{3} \mathrm{y}^{-1}$.

In the Plantation+ Scenario, conversion of $50 \%$ of the forested area to coniferous species after shortening the rotation length of broadleaved forest was found to increase wood supply to 561 million $\mathrm{m}^{3} \mathrm{y}^{-1}$ by 2065 , (Figure 5). However, this form of management would not be enough to satisfy the high demand level in this Scenario.

The supply of coniferous wood under the Plantation Scenario (556 million $\mathrm{m}^{3} \mathrm{y}^{-1}$ in 2065) would be similar to that under Plantation+ Scenario. This result suggests that shortening the rotation length of broadleaved forest in order to speed up the conversion would not increase wood supply. Lack of increase in coniferous wood supply between 2030 and 2045 (Figure 5) reflects the amount of time needed for coniferous species to reach harvestable age. High demand would exhaust the reservoir of coniferous wood that exists between 2010 and 2020.

Other results show that due to the higher achieved felling level in the Plantation+ Scenario, the growing stock rises less under this regime. Namely, the growing stock amounts to $211 \mathrm{~m}^{3} \mathrm{ha}^{-1}$ in 2065 under the plantation+ versus $242 \mathrm{~m}^{3} \mathrm{ha}^{-1}$ in 2065 under the BAU scenario.

Because the specified conversion method for both the Plantation and Plantation+ Scenarios involved felling of broadleaved forest, a demand for broadleaved wood is required to stimulate the conversion to coniferous forests. By doing the conversion this way, the conversion becomes rather slow. This inertia in the system is also visible in

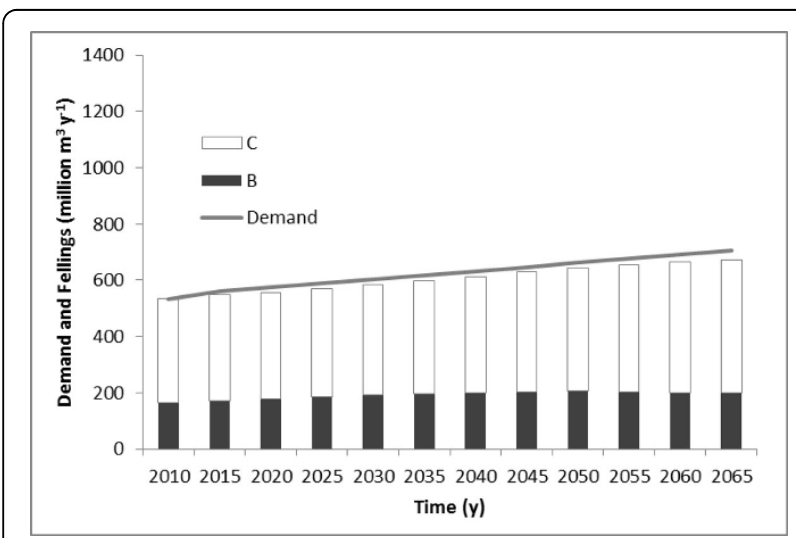

Figure 4 Total demand for wood (line) and supply of wood (bars) from coniferous (C) and broadleaved (B) forest in $25 \mathrm{EU}$ countries as projected by the EFISCEN model under a Business as Usual Scenario.

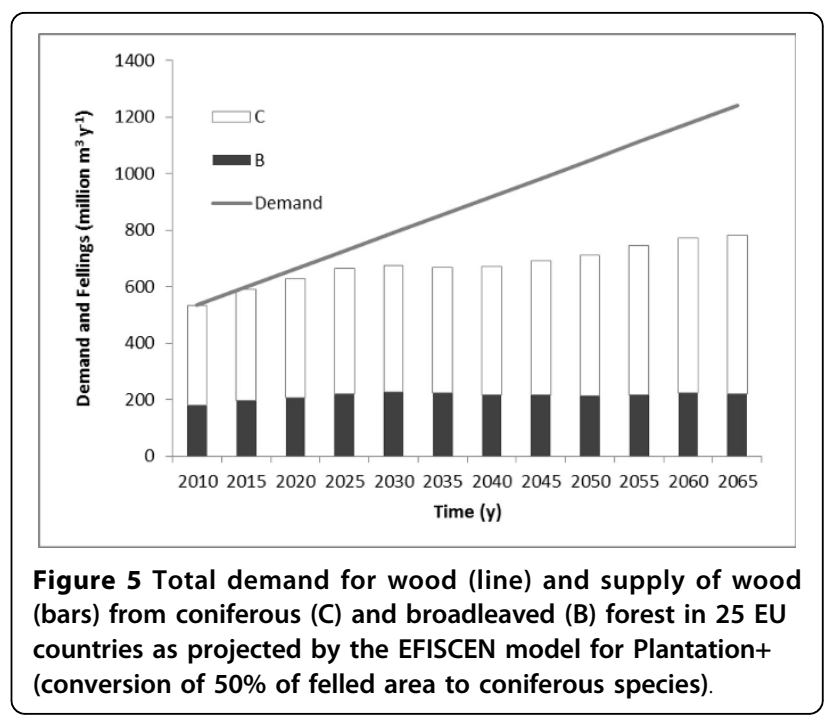

Figure 6, where net annual increment for all forests is depicted. Only after 2045, the increment in both the plantation scenarios starts to increase compared to BAU, due to an increase in area of faster growing plantations. In 2065, in both plantation scenarios, net annual increment could rise to $7.4 \mathrm{~m}^{3} \mathrm{ha}^{-1} \mathrm{y}^{-1}$, while remaining at $6.8 \mathrm{~m}^{3} \mathrm{ha}^{-1} \mathrm{y}^{-1}$ under BAU scenario.

\section{Discussion}

Conversion of broadleaved forests to coniferous forest plantations as specified in the three Scenarios tested would be gradual, and initiated only when the broadleaved species are at final felling age. However, it implies that part of the wood supply would be derived from broadleaved species as conversion takes place. A shift in proportion of the demand for broadleaved wood at the beginning of the 50-year period could speed up the conversion process.

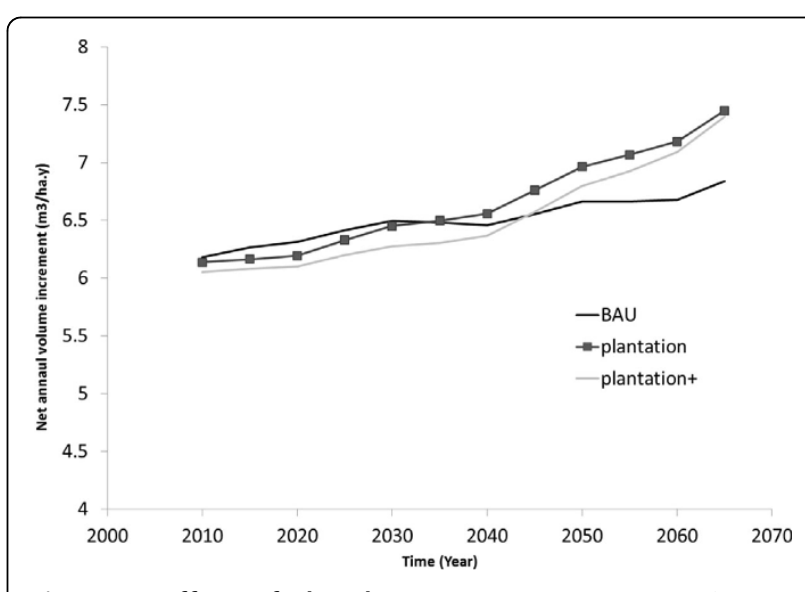

Figure 6 Effect of the three management scenarios on predicted net annual increment in forests of $25 \mathrm{EU}$ countries 
Harvesting constraints due to lack of owner cooperation, biodiversity considerations or site constraints were not included in any of the scenarios tested. More detailed analyses taking account of other functions of the forest (e.g. maintenance of biodiversity) will be required if the traditional European attitude to multifunctionality is to be maintained while still allowing for a larger felling volume. The authors do not advocate large-scale conversion to planted forests in Europe.

Current trends in European forest management could result in over-supply of broadleaved wood and a shortfall of coniferous timber. Increases in harvest may be difficult to achieve due to restrictive environmental policies and the preference of many small forest owners to regard growing trees as a legacy for the next generation.

The forest sector faces a number of challenges. For example, many European countries have introduced policies to increase the proportion of renewable energy in total energy consumption. It is hoped that these policies will combat climate change and address concerns about rising fossil fuel prices and energy security. This has resulted in increased demand for wood as an energy source and substantial public and private investment in the production of bioenergy and biofuel from planted forests. Although the wood and forestry sectors can help to meet these green economy objectives, the analysis in this paper suggests that more will be needed than simple conversion of part of the broadleaved forest to faster-growing coniferous species.

\section{Conclusions}

Conversion of existing broadleaved to coniferous species as specified for EFISCEN modelling is likely to be a slow process that will not keep pace with the expected high demand for wood. It could provide an additional 10 million ha of coniferous forest in 60 years, and could increase the supply of coniferous wood by 88 million $\mathrm{m}^{3} \mathrm{y}^{-1}$ by 2065 (18\%). High demand would exhaust most of the available coniferous stock of wood in the short term, resulting in shortage of supply between 2020 and 2030.

\section{Endnotes}

${ }^{i}$ The Food and Agriculture Organisation (FAO 2010) defines a planted forest as those forests 'composed of trees established through planting and/or through deliberate seeding of native or introduced species', which includes forest plantations ${ }^{a}$ and planted semi-natural ${ }^{b}$ forests.

${ }^{\text {a }}$ Forest plantations, a subset of all planted forests, are defined as forests of introduced species and in some cases native species, established through planting or seeding, with few species, even spacing and/or evenaged stands (FAO 2006a). ${ }^{\text {b }}$ Semi-natural forests are defined as forests of native species, established through planting, seeding or assisted natural regeneration. This definition includes areas under intensive management where native species are used and deliberate efforts are made to increase/optimise the proportion of desirable species, thus leading to changes in the structure and composition of the forest, with possible presence of naturally regenerated trees from other species than those planted/seeded. This may include areas with naturally regenerated trees of introduced species and areas under intensive management where deliberate efforts, such as thinning or fertilising, are made to improve or optimise desirable functions of the forest Plantation: Forest stands established by planting or/and seeding in the process of afforestation or reforestation.

ii EU27 minus Malta and Cyprus.

\section{Competing interests}

There are no competing interests

\section{Authors' contributions}

GJN set up the experiment, and wrote most of the paper. MJS and GH did the model runs. CO, MT, and TF wrote parts of the paper, and commented it.

\section{Acknowledgements}

We are indebted to Ola Sallnäs for providing the core of the EFISCEN model in 1995, and also to the national forest inventory institutes of EU countries for supplying data. This paper was partly funded by the FP7 Trees4future Project (Grant No 284181) and FP7 SIMWOOD (613762).

\section{Declaration}

Publication of this supplement was funded by the New Zealand Forest Research Institute Limited (trading as Scion).

This article has been published as part of JOURNAL Volume 44 Supplement 1, 2014: Proceedings of the Third International Congress on Planted Forests. The full contents of the supplement are available online at http://www. nzjforestryscience.com/supplements/44/S1.

\section{Authors' details}

${ }^{1}$ Alterra, Wageningen University and Research, P.O. Box 47, 6700 AA Wageningen, The Netherlands. ${ }^{2} \mathrm{EFI}$ Atlantic, Site de Recherche Forêt - Bois, 69, route d'Arcachon, 33612 Cestas, France. ${ }^{3}$ Forest and Nature Conservation Policy group, Wageningen University, P.O. Box 47, 6700 AA Wageningen, The Netherlands. ${ }^{4}$ University of Lisbon, Lisbon, Alameda da Universidade, 1649004 Lisboa, Portugal. ${ }^{5}$ University College, Belfield, Dublin 4, Ireland.

\section{Published: 26 November 2014}

\section{References}

Bolte A, Ammer C, Löf M, Madsen P, Nabuurs GJ, Schall P, Spathelf P, Rock J: Adaptive forest management in central Europe: Climate change impacts, strategies and integrative concept. Scandinavian Journal of Forest Research 2009, 24:473-482.

Brus DJ, Hengeveld GM, Walvoort DJJ, Goedhart PW, Heidema AH, Nabuurs GJ, Gunia K: Statistical mapping of tree species over Europe. European Journal of Forest Research 2011, 131(1):145-157.

CEPF: 2013 [http://www.cepf-eu.org], Retrieved from.

FAO: Global Forest Resources Assessment 2010. FAO Forestry Paper 163, Rome; 2010.

Farrell EP, Fuhrer E, Ryana D, Andersson F, Huttl R, Piussi P: European forest ecosystems: building the future on the legacy of the past. Forest Ecology and Management 2000, 132:5-20.

Forest Europe: FOREST EUROPE UNECE and FAO 2011: State of Europe's forests 2011. Status and trends in sustainable forest management in Europe. 2011 [http://www.foresteurope.org/documentos/ 
State_of_Europes_Forests_2011_Report_Revised_November_2011.pdf], Jointly prepared by FOREST EUROPE Liaison Unit Oslo, the United Nations Economic Commission for Europe (UNECE), Geneva, and the Food and Agriculture Organization of the United Nations (FAO), Rome.

Hanewinkel M, Cullmann DA, Schelhaas MJ, Nabuurs GJ, Zimmermann NE: Climate change may cause severe loss in the economic value of European forest land. Nature Climate Change 2012, doi:10.1038/nclimate1687.

Hengeveld GM, Nabuurs GJ, Didion M, VandenWyngaert IM, Clerckx APPM, Schelhaas MJ: A forest management map of European forests. Ecology and Society 2012, 17(4):53[http://dx.doi.org/10.5751/ES-05149-170453]. Lindner M, Maroschek M, Netherer S, Kremer A, Barbati A, Garcia-Gonzalo J, Seidl R, Delzon S, Corona P, Kolström M, Lexer MJ, Marchetti M: Climate change impacts, adaptive capacity, and vulnerability of European forest ecosystems. Forest Ecology and Management 2010, 259(4):698-709.

Mantau U, Saal U, Prins K, Steierer F, Lindner M, Verkerk PJ, Eggers J, Leek N, Oldenburger J, Asikainen A, Anttila P: EUwood - Real potential for changes in growth and use of EU forests. Final report. Hamburg, Germany: University of Hamburg, Centre of Wood Science; 2010 [http://ec.europa.eu/energy/ renewables/studies/doc/bioenergy/euwood_final_report.pdf]. Nabuurs GJ, Van Brusselen J, Pussinen A, Schelhaas MJ: Future harvesting pressure on European forests. European Journal of Forest Research 2006, 126:391-400.

Nabuurs GJ, Hengeveld GM, van der Werf DC, Heidema AH: European forest carbon balance assessed with inventory based methods - An introduction to a special section. Forest Ecology and Management 2010, 260:239-240.

Sallnäs O: A matrix growth model of the Swedish forest. Studia Forestalia Suecica, 183 Uppsala, Sweden: Swedish University of Agricultural Sciences; 1990, Faculty of Forestry.

Schelhaas MJ, Nabuurs GJ, Schuck A: Natural disturbances in the European forests in the 19th and the 20th centuries. Global Change Biology 2003, 9:1620-1633.

Schelhaas MJ, Eggers J, Lindner M, Nabuurs GJ, Pussinen A, Paivinen R, Schuck A, Verkerk PJ, Van der Werf DC, Zudin S: Model documentation for the European Forest Information Scenario Model (EFISCEN 3.1.3). Wageningen, The Netherlands: Alterra; 2007 [http://www.efi.int/files/attachments/publications/ alterrarapport1559.pdf], (Alterra Report 1559).

Seidl R, Schelhaas MJ, Lexer MJ: Unravelling the drivers of intensifying forest disturbance regimes in Europe. Global Change Biology 2011, 17:2842-2852. UNECE/FAO: The European forest sector outlook study II. 2010-2030. Geneva, Switzerland/Rome, Italy; 2011.

UNECE/FAO: Forest products annual market review 2012-2013. Geneva Switzerland/Rome, Italy; 2013, (Geneva Timber and Forest Study Paper ECE/TIM) $\mathrm{SP} / 33)$.

Vilén T, Gunia K, Verkerk PJ, Seidl R, Schelhaas MJ, Lindner M, Bellassen V: Reconstructed forest age structure in Europe 1950 - 2010. Forest Ecology and Management 2012, 286:203-218.

doi:10.1186/1179-5395-44-S1-S8

Cite this article as: Nabuurs et al:: European perspective on the development of planted forests, including projections to 2065. New Zealand Journal of Forestry Science 2014 44(Suppl 1):S8.

\section{Submit your manuscript to a SpringerOpen ${ }^{\mathcal{O}}$ journal and benefit from:}

- Convenient online submission

- Rigorous peer review

- Immediate publication on acceptance

- Open access: articles freely available online

- High visibility within the field

- Retaining the copyright to your article

Submit your next manuscript at $>$ springeropen.com 